\title{
EFFECT OF MANAGEMENT ON PASTURE COMPOSITION
}

SHONA M. MACLEAN, Research Officer,

Department of Agriculture, Wellington

The type of management a pasture is given determines the botanical composition of the sward and in turn influences the yield of herbage produced. Of the various aspects of pasture management, the two factors that bring about the most rapid changes in composition are length and height of grazing and chemical spraying of pastures.

The results of trials, mainly carried out at the Marton Experimental Area over the last few years, to examine the effects of different grazing and spraying treatments are the main subjects presented in this paper.

\section{The Influence of Type of Grazing on Pasture Composition and} Production: Effect of Length of Spelling

A pasture sown with perennial ryegrass, short-rotation ryegrass, cowgrass, and white clover in 1954 has, since autumn 1955, been subjected to different spelling periods between grazing as follows:

(i) Spelled 6 days,grazed and cut every 7th day. (Weekly.)

(ii) Spelled 20 days, grazed for 1-2 days, cut on 21 st day. (Three weekly short.)

(iii) Spelled 14 days, grazed for 7 days, cut on 21 st day. (Three weekly long.)

(iv) Spelled 40 days, grazed for 2 days, cut on 42nd day. (Six weekly.)

Sheep are used in this trial and if necessary, according to seasonal conditions (iv) receives the same grazing management as (ii) from October to December, but yields are still taken from (iv) at six-weekly intervals. Heavier stocking is required for the 1-2 days' grazing of the three-weekly short than for the three-weekly long, where a smaller number of sheep are used for a longer time.

The main changes in species composition that have taken place during the four years are shown in Tables 1 and 2 .

Poa trivialis comes into all pastures at Marton during their second or third year and may become the dominant species under wet summer conditions such as in the summer of 1957-58. Associated with the ingress of Poa trivialis there is a decline in the ryegrass content of the sward. Length of spelling has not prevented 
P. trivialis from becoming the dominant species in all pastures (as shown by the percentage cover figures in Table I), but, longer spelling has reduced the amount of growth of $P$. trivialis and has at the same time encouraged the growth of ryegrass (see Table 2.) Even three-weekly short grazing has had much the same effect as six weeks' spelling, but to a less extent.

Short-rotation ryegrass was a dominant species of the pasture in 1954, but declined rapidly during the summer of 1954-55 before length of spelling treatments were started. Although only a minor species in the sward from then on, the longest spell has encouraged the growth and subsequent increase of short-rotation ryegrass. Cowgrass (not given in the table) persisted for the first two years, and again longer spelling encouraged its growth. White clover formed a very small proportion of the sward for the first two years, and no doubt the heavy seeding rate of ryegrass $(20 \mathrm{lb}$ of perennial and $20 \mathrm{lb}$ of short-rotation ryegrass) when the pasture was sown was the major cause of its suppression. The main effect of length of spelling was to encourage more cover. of white clover in paddocks under frequent grazing, but during the wet conditions which prevailed last season, three-weekly short and six-weekly spellings have both produced more cover of white clover, the plants being larger and leafier, consequently giving greater production than on other treatments. Weeds have remained a fairly small constituent of the pasture. The frequent grazings of the weekly and three weekly long treatments produced a weedy pasture, particularly during early summer, when pennyroyal was "prevalent. The more upright growth and open nature of the sixweekly spelling allowed the ingress of docks.

The effect of spelling on production has been referred to at a previous conference when the results of a small plot trial were presented* Table 3 and Fig. 1 show how the production increases as length of spelling increases, the greatest amount of growth being made during the last three weeks. Six-weekly spelling and three-weekly short grazing gave average increases of $5000 \mathrm{lb}$ and $2000 \mathrm{lb}$ of dry matter per acre per annum respectively. Although six-weekly spelling has given the biggest increase in yield, the three-weekly short has the better quality pasture, as the continued long spelling has opened up the sward. In practice, time of grazing should not be governed by a time interval but be governed according to length of growth. Other trial work, where length of spelling is investigated in conjunction with height of cutting (pasture cut back to two heights-13 in and $\frac{3}{4}$ in), has shown that longer growth (4 in-6 in) cut back to a height of $1 \frac{1}{2}$ inches promotes the growth of ryegrass, timothy, cocksfoot, and white clover, but reduces the cover and growth of Poa trivialis. It is indicated that 
this reduction in P. trivialis is even greater when the growth is cut back to $\frac{3}{4}$ in. One of the most noticeable features of longer growth cut back to $1 \frac{1}{2}$ in in height is the large-leaved white clover which develops on this treatment.

\section{length of spelling}

weekly

3 weekly short

dry matter lb per acre

6 weekly

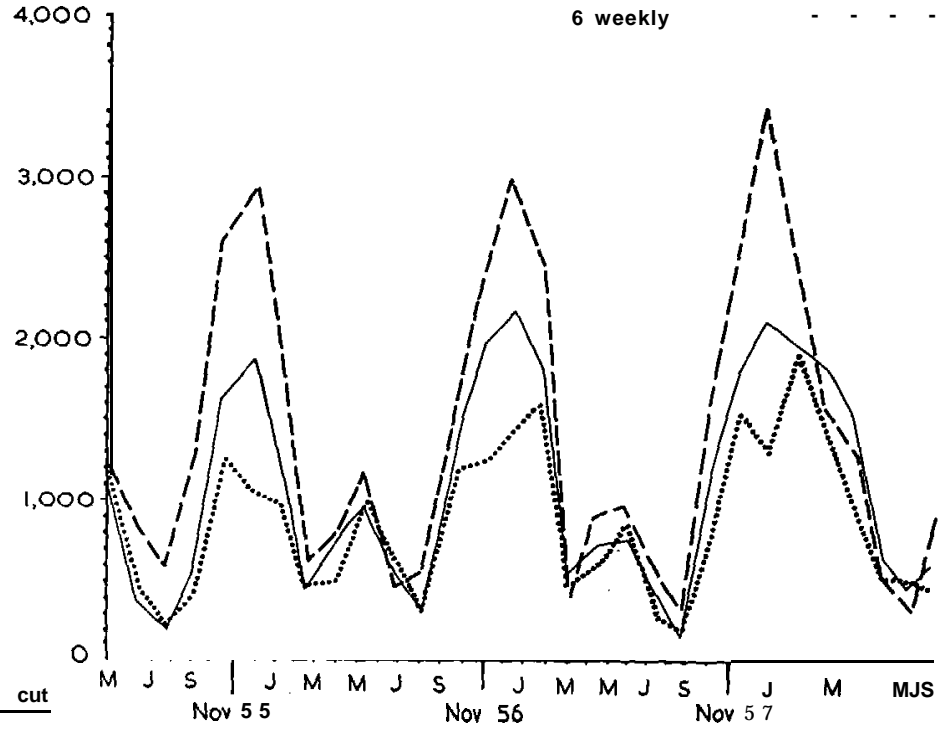

Fig. 1--Effect of spelling on pasture production.

\section{The Influence of Spraying on Pasture Composition and}

\section{Production}

Although height and frequency of grazing can bring about marked changes in the composition and yield of a pasture, the most rapid changes are brought about by spraying with chemicals, whether they are used to aid the establishment of oversown species in low fertility unimproved swards and in run-out pastures or to control weeds in a high fertility sward.

The greatest changes in species composition brought about by the use of chemicals with oversowing and topdressing take place in a low fertility unimproved sward. A browntop-danthoniadominant sward can be changed within a few months to a ryegrasswhite clover sward with a few weed grasses. The main limitations 
of oversowing and topdressing without chemical sward destruction is that few oversown grasses establish in a tight turf mat; therefore the use of chemicals appears warranted on low fertility pasture devoid of the better grasses. In run-out pastures, however, where remnants of ryegrass, cocksfoot, and a good producing strain of clover are present, marked improvements with oversowing and topdressing alone, combined with controlled, correct grazing management can be brought about, although a quicker improvement in the botanical composition can still be made with a chemical.

The effect of oversowing, topdressing, and spraying on such a run-out pasture containing nearly 20 per cent of ryegrass has been examined in a oasture measurement trial over the last year. The results of this trial are a good example of the general changes that take place after spraying, oversowing, and topdressing. Differences in species composition are shown in Table 4.

The immediate main advantages of spraying were the improved establishment of ryegrass, red clover, and pedigree white clover and the quick reduction in weed grasses (browntop, sweet vernal, and Yorkshire fog).

A year after sowing, the difference in ryegrass content between the oversown and topdressed area and the sprayed areas was less noticeable. The ryegrass appeared to have been suppressed in the sward by the dense growth of Poa trivialis, which had become a dominant species in the sward under improved conditions of fertility and under wet summer conditions. Unfortunately, during spring, the mowing was not usually carried out frequently enough to control the rapid growth of the ryegrass-dominant sward on the sprayed area. The sprayed area was rather open and in an ideal condition for the ingress of $P$. trivialis.

The effect of these changes in species composition on production is shown in Table 5. The sprayed areas were lower yielding during spring and early summer than the oversown and topdressed, but from mid-summer on, when the clover content of the two areas was similar, they were equal in yield, and at the last cut in June the sprayed areas outyielded the oversown and topdressed. Thus, although a marked improvement in the content of ryegrass may be achieved by spraying, the total yearly production will show no improvement compared with the result obtained by oversowing and topdressing the original pasture where some ryegrass is already present until the proportion of clover reaches 30 per cent of the sward.

A good balance of grass to clover in high fertility swards is essential for maximum production, and if the amount of clover is reduced, both the grass composition and the production of the 
sward as a whole are affected. This has been shown in a trial where weedkillers have been used as a means of reducing the clover content.

The trial was sown with a mixture of perennial ryegrass, cocksfoot, red clover, and white clover in spring 19.54, and in early December 1955 the first application of 2,4-D and 2,4,5-T was made. Repeat sprayings aimed at varying the proportion of clover from "much" on the unsprayed areas, to "some" on the 2,4-D areas, to "trace" on the 2,4,5-T areas have since been carried out.

\section{Effect of Clover Suppression on Pasture Composition}

By December 1957 (two years after the first spraying) a number of changes in the botanical composition had taken place (see table 6).

Both weedkillers caused a marked reduction in red and white clover at the first spraying, white clover being a little more tolerant of 2,4-D. Since then little red clover has been present in the sward, but white clover has gradually returned, particularly during spring 1957 on the 2,4-D areas, which had not been sprayed since April 1957. Some of this white clover was a small-leafed volunteer strain which provided plenty of ground cover but was a less productive type than the sown white clover. It has proved to be more tolerant of the weedkillers, and it has been necessary to use a higher rate of 2,4,5-T to keep the clover content of these areas reduced to the minimum.

The increase of white clover on the 2,4-D sprayed area is a usual result of spraying with hormone weedkillers in a mixed sward of red and white clover. The suppression of one clover and the subsequent lack of competition allow the more tolerant clover to increase rapidly in the sward, which leads to a dominance of the tolerant clover.

Clover suppression did not affect the proportion of ryegrass in the sward, although with only a trace of clover it became harsh, wiry, and prostrate in growth habit. Less cocksfoot, however, was present with little clover and the sward had also become more open, allowing an ingress of Poa annua and weeds (sorrel and Sagina procumhens). The reduction in cocksfoot on the areas with little clover took place during winter 1957 after severe burning of the leaf tips in July under frosty conditions. In contrast, the cocksfoot on the areas with much clover was not frosted in winter and also made good, vigorous growth in late autumn. Thus, in the nonvigorous, clover-deficient sward lacking in nitrogen, cocksfoot was more susceptible to frost. One spraying of a vigorous, well-balanced sward with 2,4-D at the end of autumn 1956 in another trial resulted in a reduction of cocksfoot in the sward. In this case 
increased competition from perennial ryegrass would most probably have been responsible, as it appeared to make vigorous growth at that time of the year after clover suppression.

\section{E ffect of Clover Suppression on Production}

Yield data are presented in Table 7 and in Fig. 2.

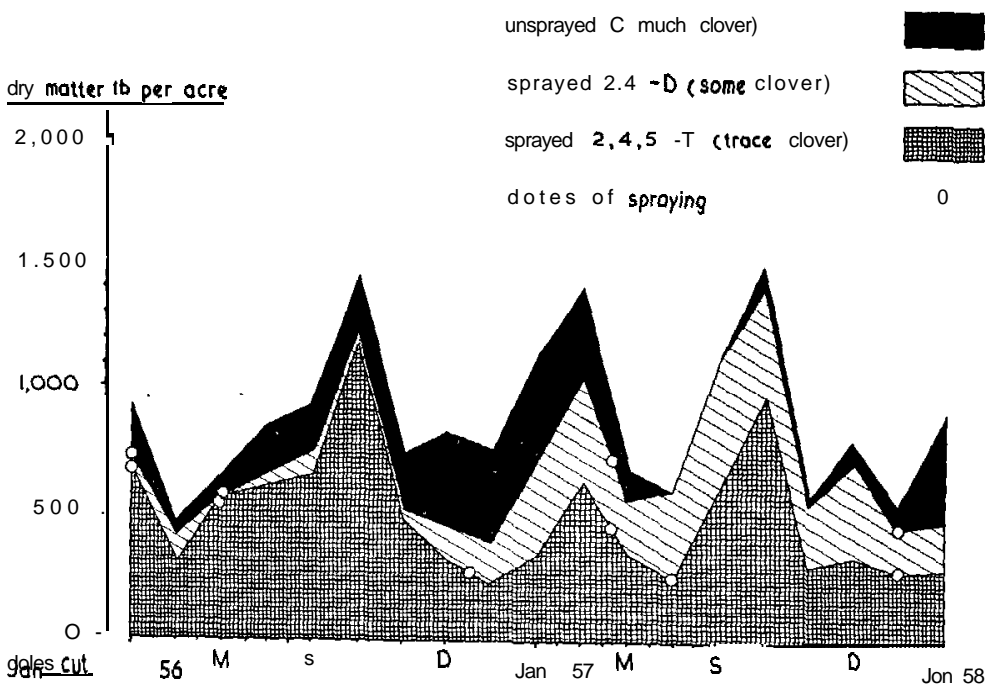

Fig. 2-Effect of clover suppression on pasture production.

With the reduction in clover, yields were considerably reduced from early spring onwards once clover began its spring growth. The more severely the clover was suppressed, the greater was the loss in production, and as clover returned in the 2,4-D area, the difference between it and the unsprayed diminished. Where there was much clover the pasture was more thrifty, the grass longer and more succulent. Although the yield for winter 1957 was higher on the 2,4-D area, this was not a significant increase, but any reduction of 5 per cent and more in yield was statistically significant.

\section{E ffect of Clover Suppression on Soil Analysis}

Of interest also is the effect of clover suppression and subsequent reduced growth on the potash and phosphate content of the soil. An analysis in autumn 19.58 gave significantly higher values for phosphate and also indicated that potash was higher. Results were as follows: 


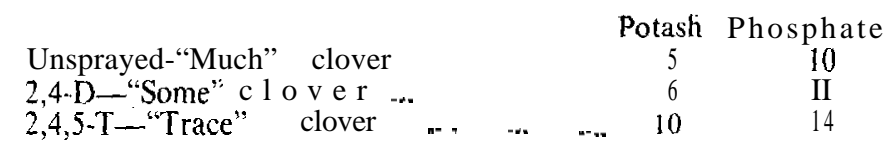

\section{Effect of "Fertiliser" Nitrogen on Pasture Composition and Production}

This year, nitrolime at $\frac{1}{2}$ cwt per acre has been applied to half the plots after each cut. The yield of 2,4,5-T ("trace clover") areas from January to early August 1958 has improved by 47 per cent, but this is still 13 per cent less productive than the unsprayed areas. Even the unsprayed areas with much clover have given a 7 per cent increase in yield with nitrogen, and on the 2,4-D areas a 15 per cent increase in yield was obtained. The application of "fertiliser" nitrogen has not reduced the clover content of the sward, the clovers appearing more vigorous with the nitrogen in August 1958.

The greatest benefit from an application of fertiliser nitrogen is seen in autumn to late winter and again in early spring, at which times it mainly increases the growth of ryegrass. It is important to control the height of grazing at this time of year, or the vigorous growth of grass if allowed to grow long will suppress the clover and if this happens a reduction in yield will occur later.

In a low-fertility sward that is being renovated with the aid of chemicals, nitrogen may have a possible use to assist the breakdown of the old sward and encourage the seedling grasses to establish, but this has to be confirmed by further trial work. Again, height of grazing must be carefully controlled, as the establishing clovers appear very sensitive to lack of light and any advantage of the applied nitrogen will soon he lost unless the clovers are making good growth by mid-spring after an autumn sowing.

\section{Conclusions}

1. Adequate spelling of pastures between grazings to give growth 4-6 in in height encourages the growth of perennial ryegrass, shortrotation ryegrass, timothy, cocksfoot, and white clover, but reduces the growth of Poa trivialis.

2. Grazing should be carried out according to length of growth and not according to a time interval. Continued long spelling of six weeks produces an open sward and under dry conditions is less productive than three weekly spelling. If possible, pastures should not be hard grazed before the onset of dry weather or weeds will become prevalent,

3 . Any reduction of clover in a well-balanced sward is correlated with a reduction in total yield over the whole year. 
4. Suppression of one major species in a sward by chemicals quickly results in the dominance of the more tolerant species if it is making active growth at the time of application. Thus, ryegrass may be increased in a clover dominant sward by spraying.

5. Use of a nitrogenous fertiliser in a well-balanced sward is beneficial for extending the growing season by providing earlier and later growth, but does not compensate for lack of clover. Care must be exercised in controlling the height of grazing so that clovers are not suppressed by the increased longer growth of the grasses. It is indicated that an application of nitrogen in late autumn may reduce frost damage to cocksfoot.

6. If a sward is deficient in clover, growth of ryegrass and cocksfoot is reduced and weeds and Poa annua soon become prominent.

7. Topdressing and oversowing bring about a substantial reduction in weed grasses, but a much quicker and greater reduction may be obtained with the use of chemicals. In particular, the establishment of grasses and red and subterranean clover is aided by chemical sward destruction.

8. Any pasture improvement programme by oversowing with or without chemicals must be accompanied by a good grazing management suited to the oversown species.

Table I.--E ffect of Spelling on Pasture Composition.

\section{Percentage Cover}

\begin{tabular}{|c|c|c|c|c|c|}
\hline Snecies & Year & Weekly & $\begin{array}{l}3 \text { Weekly } \\
\text { Short }\end{array}$ & $\begin{array}{l}3 \text { Weekly } \\
\text { Long } 6\end{array}$ & Weekly \\
\hline Perennial & Aug. '54 & 40 & 37 & 41 & 42 \\
\hline \multirow[t]{3}{*}{ Ryegrass" } & $" 55$ & 61 & 61 & 63 & 55 \\
\hline & "56 & 69 & 72 & 69 & 63 \\
\hline & $\Rightarrow 58$ & 44 & 38 & 33 & 40 \\
\hline \multirow{4}{*}{$\begin{array}{l}\text { Short- } \\
\text { rotation } \\
\text { Ryegrass }\end{array}$} & Aug. '54 & 4.5 & 47 & 44 & 45 \\
\hline & ‘55 & I & 1 & 2 & 5 \\
\hline & ‘56 & $\operatorname{Tr}$ & 2 & 1 & 7 \\
\hline & $"$ "58 & $\operatorname{Tr}$ & 1 & 2 & 9 \\
\hline \multirow{4}{*}{$\begin{array}{l}\text { White } \\
\text { Clover }\end{array}$} & Aug. '54 & 3 & 5 & 4 & 4 \\
\hline & ‘55 & 11 & 13 & 12 & 14 \\
\hline & '56 & 18 & 10 & 16 & 13 \\
\hline & '58 & II & 18 & 13 & 23 \\
\hline \multirow{4}{*}{$\begin{array}{l}\text { POU } \\
\text { frivialis }\end{array}$} & Aug. '54 & $\mathrm{Tr}$ & $\mathrm{Tr}$ & $\operatorname{Tr}$ & $\mathrm{Tr}$ \\
\hline & $" 55$ & $\operatorname{Tr}$ & $\operatorname{Tr}$ & $\mathrm{Tr}$ & $\mathrm{Tr}$ \\
\hline & "' '56 & 21 & 15 & 9 & 4 \\
\hline & 58 & 52 & 65 & 64 & 46 \\
\hline
\end{tabular}

* Botanical analysis in 1954 carried out before differential grazing treatments had started. 
Table 2_-Effect of Spelling on Growth of Species. Mean Percentage of Species in Herbage over Several Years,

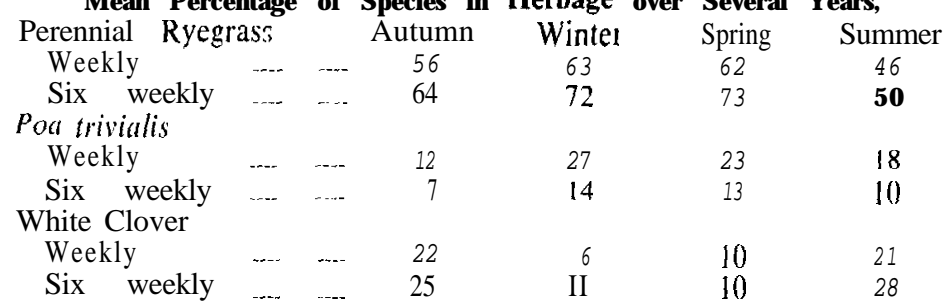

Table J.-Effect of Spelling on Yearly Production.

(Yields of dry matter in pounds per acre)

Year $1955-56(2.6 .55$ to 10.556$)$

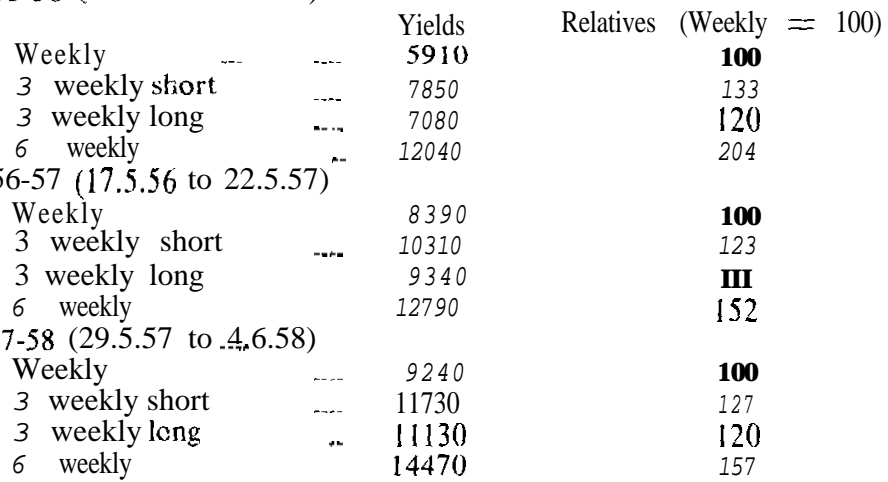

Table 4.-Changes in Species Composition Following Topdressing aud Oversowing and Spraying in April, 1957.

Percentage Cover

Perennial Ryegrass

Control (no improvement) ....

Oversown and topdressed

Not analysed

* Sprayed, oversown, and topdressed

44

Autumn '58

Clover (White and Red)

Control (no improvement) ... Not analysed

Sprayed, oversown, and topdressed

$\begin{array}{ll}47 \\ 23 & (6)\end{array}$

Poa trivialis

$$
(\mathrm{l})=- \text { amount of red clover in per cent clover. }
$$

Control (no improvement) Not analysed 24

Oversown and topdressed ... $\quad 13 \quad 41$

Sprayed, oversown, and topdressed ... $\quad 13 \quad 42$

Wced Grasses

$\begin{array}{ccc}\text { Control (no improvement) } & \text { Not analysed } & 64 \\ \text { Orer. } & 63 & 36\end{array}$

$\begin{array}{lrl}\text { Oversown and topdressed } & 63 & 36 \\ \text { Sprayed, oversown, and topdressed ..... } & 13 & 13\end{array}$

Wceds

Control (no improvement) .... Not analysed 18

$\begin{array}{lll}\text { Oversown and topdressed } & 15 & 11\end{array}$

Sprayed, oversown, and topdressed .... 12

* Chemicals used-Dalapon 5 lb., Amitrol I 1b/ac. 
Table 5,-Effect of Topdressing and Oversowing and Spraying on Production Yields of Dry Matter (lb/ac.) 1957.58

Part

Control (no improvement) \begin{tabular}{ccccccc} 
Winter & Spring & Summer & Autumn & Total Relative \\
\hline & $\mathbf{3 6 8 0}$ & $\mathbf{2 6 1 0}$ & $\mathbf{1 4 7 0}$ & $\mathbf{8 2 3 0}$ & 100
\end{tabular}

Oversown and topdressed $\begin{array}{lllllll}410 & 4340 & 3440 & 2810 & 10990 & 133\end{array}$

Sprayed, oversown and t/d. $\quad \begin{array}{llllll}3550 & 3380 & 3060 & 9990 & 121\end{array}$

Table 6.-Effect of Clover Suppression on Pasture Composition. Percentage Cover at December 1957.

\begin{tabular}{|c|c|c|c|c|c|}
\hline & & & & & \\
\hline & & & $\begin{array}{l}\text { nsprayed } \\
\text { "much" }\end{array}$ & $\begin{array}{l}\text { 2,4-D } \\
\text { "some" }\end{array}$ & $\begin{array}{l}2,4,5-T \\
\text { "trace" }\end{array}$ \\
\hline Species & & & clover & clover & clover \\
\hline & White clover & 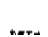 & 49 & 60 & 17 \\
\hline & Red clover & & 21 & 1 & 5 \\
\hline & Ryegrass $\quad . .$. & "דeר & 30 & 33 & 35 \\
\hline & Cocksfoot & 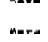 & 24 & 21 & 15 \\
\hline & annua & היה & 6 & 9 & 14 \\
\hline & Other grasses & na- & 2 & 1 & 4 \\
\hline & Weeds & & 6 & 1 & 16 \\
\hline & Bare ground & & 11 & 12 & 33 \\
\hline
\end{tabular}

Dates sprayed: 2,4-D applied on 9.12.55, 21.5.56 and 8.4.57.

2,4,5-T applied on the above dates and also on 7.12 .56 and $10.7 .5 \%$

\begin{tabular}{|c|c|c|c|c|c|c|}
\hline Table 'I.-E ffec & $\begin{array}{l}\text { of Clover } \\
\text { Yield } \\
\text { DM. } 1 b / a c\end{array}$ & \multicolumn{2}{|c|}{$\begin{array}{l}\text { Suppression on } \\
\text { Yield relative to } \\
\text { unsprayed }=100\end{array}$} & \multicolumn{3}{|c|}{$\begin{array}{l}\text { Pasture Production. } \\
\text { Proportion of Clover } \\
\text { Percentage in Herbage }\end{array}$} \\
\hline $\begin{array}{l}\text { Season } \\
\text { rt Summer }\end{array}$ & $\begin{array}{l}\text { Unsprayed } \\
\text { "Much } \\
\text { clover" }\end{array}$ & $\begin{array}{l}2,4=D \\
\text { "Some } \\
\text { clover" }\end{array}$ & $\begin{array}{l}2,3,5 \mathrm{~T} \\
\text { "Trace } \\
\text { clover" }\end{array}$ & $\begin{array}{l}\text { Unsprayed } \\
\text { "Much, } \\
\text { clover" }\end{array}$ & $\begin{array}{l}\text { 2,4-D } \\
\text { "Some } \\
\text { clover" }\end{array}$ & $\begin{array}{l}2,4,5-T \\
\text { "Trace } \\
\text { clover" }\end{array}$ \\
\hline$' 55 / 56$ & 1070 & 79 & 75 & 30 & 5 & $\operatorname{Tr}$ \\
\hline tumn '56 & 1460 & 93 & 93 & 20 & 10 & $\mathrm{Tr}$ \\
\hline ‘56 & 810 & 88 & 83 & 10 & $\operatorname{Tr}$ & $\mathrm{Tr}$ \\
\hline ing ' 56 & 3400 & 74 & 67 & 33 & 13 & 4 \\
\hline nmer ' $56 /$ '57 & 2840 & 63 & 34 & 63 & 44 & 3 \\
\hline umn '57 & 1540 & 87 & 46 & 62 & 46 & 6 \\
\hline nter '57 & 680 & 109 & 53 & 25 & 21 & 1 \\
\hline ' 57 & 3590 & 9.5 & 55 & 30 & 29 & 5 \\
\hline & & - & 42 & $r$ & 21 & \\
\hline
\end{tabular}

\section{Reference*}

Importance of spslling in pasture production by C. J. Hamblyn, N.Z. Grass. Assoc. 16- 132.

\section{Acknowledgment}

The author acknowledges with thanks the assistance of Mr J. Heywood and staff at the Marton Experimental Area in carrying out the trials described. 


\section{DISCUSSION}

Q. (Dr P. D. Sears): What grazing techniques were used'? Self contained set stocked plots result in unpalatability effects.

A. The three paddocks of- each spelling treatment were not set stocked. After having been lightly fed for several days, a mdb of sheep was put in each paddock at the end of each period of spelling, The number of sheep varied according to the amount of feed and length of grazing period. Some difficulty was experienced under wet weather conditions with the large mob of sheep required to eat up the feed within one to two days on the six weekly and three weekly short spelling treatment, as the pasture became pugged and dirty:

Q. (A. Stuart): will speaker comment of claims that. the future role of. weedkilling chemicals will be to control pasture constituents according to need.

A. Agieed, but weedkillers' should only be used in coniunction with the correct fertiliser requirements and a good grazing management, or else, little permanerit improvement in pasture composition will be achieved.' Better results have been obtained under good growing conditions. If 'dry weather follows spraying, there is likely to be a loss in production and a poor replacement of the killed species by more desirable species.,

Q. (Mr Little): What is the basic mixture used in spelling trial?

A. The pasture mixture sown in August 1954 was:

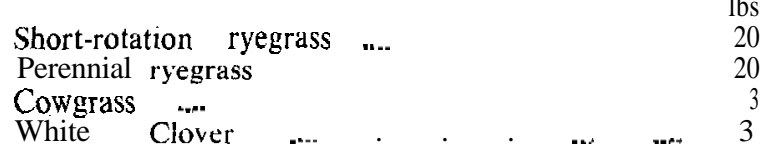

